\title{
Selective Removal of Sodium Ions from Aqueous Media Using Effective Adsorbents: Optimization by RSM and Genetic Algorithm
}

\author{
Lei Yao, ${ }^{1, \star}$ Chao Hong, ${ }^{2}$ Hani Dashtifard ${ }^{3}$ and Hossein Esmaeili ${ }^{4}$ \\ ${ }^{1}$ College of Civil and Architecture Engineering, Chuzhou University, Chuzhou 239000, Anhui, China \\ ${ }^{2}$ Nanjing Siweipu Environmental Protection Technology Co., Ltd., Nanjing 210000, Jiangsu, China \\ ${ }^{3}$ Department of Chemical Engineering, Bushehr Branch, Islamic Azad University, Bushehr, Iran \\ *Corresponding author: E-mail: yaolei@chzu.edu.cn
}

Received: 02-19-2021

\begin{abstract}
This study aimed to determine the best adsorbent among Moringa oleifera-derived activated carbon (AC), eggshell-derived $\mathrm{CaO}$ nanoparticles and $\mathrm{CaO} / \mathrm{Fe}_{3} \mathrm{O}_{4}$ for sodium $\left(\mathrm{Na}^{+}\right)$removal from aqueous media. In the first step, the appropriate adsorbent for sodium adsorption was determined among the three adsorbents, which the results showed that the AC had the highest sorption efficiency. Then, response surface methodology (RSM) was used to evaluate the impact of different factors on the $\mathrm{Na}^{+}$ion sorption efficiency using the AC. The highest removal efficiency was obtained to be $95.91 \%$ at optimum conditions such as $\mathrm{pH}$ of 11 , contact time of $45 \mathrm{~min}$, temperature of $25^{\circ} \mathrm{C}$, sodium ion concentration of 900 $\mathrm{mg} / \mathrm{L}$, and adsorbent dosage of $5 \mathrm{~g} / \mathrm{L}$. Also, the best conditions using the genetic algorithm was obtained at contact time of $94.97 \mathrm{~min}$, adsorbent dosage of $3.52 \mathrm{~g} / \mathrm{L}, \mathrm{Na}^{+}$ion concentration of $939.92 \mathrm{mg} / \mathrm{L}$ and $\mathrm{pH}$ value of 10.92 . Moreover, the maximum sorption capacity using the Langmuir model was obtained to be $249.67 \mathrm{mg} / \mathrm{g}$, which was a significant value. Besides, the equilibrium and kinetic studies indicated that the experimental data of sodium adsorption process were fitted well with the Langmuir isotherm model and the pseudo-second-order kinetic model, respectively. Furthermore, the thermodynamic study indicated that the sorption process was endothermic. Generally, among the three adsorbents used, activated carbon with a high removal efficiency and significant sorption capacity can be considered as a promising adsorbent for the removal of sodium from wastewater on an industrial scale.
\end{abstract}

Keywords: Adsorption, sodium, Moringa oleifera, Response surface methodology (RSM), Genetic algorithm

\section{Introduction}

For the past several decades, there has been a growing concern about water pollution, which affects animals, plants, and humans. ${ }^{1,2}$ Sea water is a good source of sodium ion, the salinity which does not allow humans to consume it. Sodium ion is a major component in the sea water, where its weight percent is about 16 times higher than magnesium ions, about 22 times higher than sulfur ions and about 48 times higher than bromine and potassium ions. ${ }^{3}$ The shortage of water resources and the risk of water crisis in the world as well as the pollution of surface and underground water resources with sodium ion and other pollutants from industrial and municipal sewage has made it necessary to find environmentally acceptable solutions for the elimination of these contaminants from water. ${ }^{4}$ The main sources of water pollution with sodium are human activities. Excessive consumption of sodium over the standard level causes various sicknesses like high blood pressure, the risk of cardiovascular illnesses, heart attack, and damages to kidneys. ${ }^{5}$

There are various methods to eliminate pollutants from wastewater, including ion exchange, reverse osmosis, biological process, electrodialysis, distillation, and chemical precipitation. ${ }^{6}$ The reverse osmosis and ion exchange processes can't selectively eliminate sodium ion and require continuous regeneration; these two processes do not make any chemical changes in sodium and result in pollut- 
ed wastewater. ${ }^{7,8}$ The biological process is mainly applied to wastewater and is not preferred for water treatment processes due to the application of organic materials and the need for maintenance. Furthermore, the resultant biological sludge needs to be treated before disposal. ${ }^{9}$

Adsorption process is more effective than other techniques in the elimination of pollutants, even at low concentrations $(1 \mathrm{mg} / \mathrm{L}) .{ }^{10}$ Depending on the type of the adsorbent, this simple and applicable method is superior from the aspects of capital cost, reuse of wastewater, simplicity, and flexibility of design, easy operation, and insensitivity to toxic compounds and pollutants. ${ }^{11,12}$

One of the main adsorbents used in this field is activated carbon $(\mathrm{AC})$, which is made from various herbal resources. Activated carbon can be used to remove metal ions from water and wastewater due to many advantages such as the simplicity in its synthesis, high specific surface area, high sorption performance, low-cost, and ability to remove low concentrations of heavy metal ions. ${ }^{13-15}$

Iron oxide nanoparticles are also known to be an available, cheap, and environmentally friendly material for effective sorption of pollutants due to their easy synthesis process. The magnetic nature of these nanoparticles allows their easy separation from pollutants through an external magnetic field. Considering some properties like the area to volume ratio, easy separation, recovery of nanoparticles by using an external magnetic field, low toxicity, and possibility of surface modification of nanoparticle resulted in their high efficiency of sorption. Also, the surface of magnetic materials can be modified by other materials such as $\mathrm{CaO}$ to increase their adsorption capacity. ${ }^{16-18}$

Moreover, the eggshell is an important adsorbent for the elimination of dyes and heavy metals from wastewater and has been applied several times in previous studies. ${ }^{19}$

Different adsorbents have been used so far for removal of sodium ions from aqueous solutions, which some of them are included zeolites, ${ }^{4}$ chitosan, ${ }^{20}$ activated carbon made from rice husk ${ }^{21}$ and polyantimonic acid. ${ }^{22}$

This study aims to compare the ability of cheap adsorbents like AC made from Moringa oleifera leaf, eggshell-derived $\mathrm{CaO}$ nanoparticles, and $\mathrm{CaO} / \mathrm{Fe}_{3} \mathrm{O}_{4}$ composite in the removal of sodium ion from synthetic wastewater, which these adsorbents have not been used to remove sodium ions in previous studies. Different analyses such as X-ray diffraction (XRD), scanning electron microscope (SEM), Brunauer-Emmett-Teller (BET), and Fourier-transform infrared spectroscopy (FTIR) were used to determine the surface properties of the activated carbon. Also, different parameters such as temperature, contact time, $\mathrm{pH}$, and sorbent dosage were studied on the $\mathrm{Na}^{+}$ion removal, and the best conditions were obtained using the response surface method (RSM). Also, the equilibrium, kinetic, and thermodynamic behaviors of the sorption process were studied. Moreover, genetic algorithm method was applied to optimize the best conditions for $\mathrm{Na}^{+}$removal using the $\mathrm{AC}$, which is another innovation of this research.

\section{Materials and Methods}

\section{1. Chemicals}

In this work, $\mathrm{FeCl}_{2} \cdot 4 \mathrm{H}_{2} \mathrm{O}$ and $\mathrm{FeCl}_{3} \cdot 6 \mathrm{H}_{2} \mathrm{O}$ were purchased from Merck Co. (Germany, purity $>99 \%$ ) and were used for preparing iron oxide. Sodium chloride $(\mathrm{NaCl}$, purity $>99 \%)$, sodium hydroxide $(\mathrm{NaOH}$, purity $>99 \%)$ and hydrochloric acid $(\mathrm{HCl}$, purity $=37 \%)$ were all supplied from Merck Co. (Germany). For the preparation of stock solution with $1000 \mathrm{ppm}$ concentration, $2.543 \mathrm{~g} \mathrm{NaCl}$ was dissolved in $1000 \mathrm{ml}$ double distilled water. For preparing other solutions with lower concentrations, the stock solution was diluted with double distilled water.

\section{2. Preparation of Activated Carbon from Moringa Oleifera Plant}

The Moringa oleifera is a native plant of Bushehr province (Iran), which was utilized to produce AC. To do this, the Moringa oleifera leaves were placed in a furnace at $650{ }^{\circ} \mathrm{C}$ for 4 hours and then was pulverized and sieved by a 25-mesh size sieve. Then, the resultant powder was kept in glass bottles for uptake tests. To determine surface characteristics of the AC, XRD, SEM, BET, and FTIR analyses were carried out. The XRD analysis was used to determine the crystalline phases of the AC. Additionally, SEM and FTIR analyses were done to determine the morphology and functional groups in the AC structure, respectively. Also, BET analysis was applied to determine the specific surface area of the adsorbent.

\section{3. Preparation of $\mathrm{CaO}$ and $\mathrm{CaO} / \mathrm{Fe}_{3} \mathrm{O}_{4}$ from Eggshell Waste}

To prepare $\mathrm{CaO}$, eggshell wastes were first washed for several times with tap water and then was placed in an oven at $105^{\circ} \mathrm{C}$ to be dried completely. After being dried, the eggshells were placed in a furnace at $800^{\circ} \mathrm{C}$ for 4 hours. After this time, the eggshells were cooled down at room temperature. The calcined eggshells were pulverized in a mill and then stored in plastic bottles. ${ }^{13}$ To support $\mathrm{Fe}_{3} \mathrm{O}_{4}$ nanoparticles on the $\mathrm{CaO}$ structure obtained from eggshells, a solution containing $\mathrm{Fe}^{+3}$ and $\mathrm{Fe}^{+2}$ with a 2:1 molar ratio was prepared. Then, about $1 \mathrm{~g}$ of $\mathrm{CaO}$ was added to the solution and it was blended for 20 min with mixing rate of $400 \mathrm{rpm}$. Then, sodium hydroxide with $3 \mathrm{M}$ concentration was added dropwise to this solution, and the oxidation process progressed. The addition of sodium hydroxide was continued until a black colored solution was obtained. Afterwards, the prepared adsorbent was separated from the solution and washed with distilled water several times to be neutralized. After that, the adsorbent was placed in an oven at $105^{\circ} \mathrm{C}$ for 24 hours to be completely dried. The dried adsorbent was then pulverized to be used in the uptake of sodium ion. 


\section{4. Adsorption Test}

The experiments were performed in a $200 \mathrm{ml}$ Erlenmeyer, which were filled with $100 \mathrm{ml}$ of sodium solution. Then, the impact of various factors like sodium concentration (300-1500 ppm), contact time (15-75 min), pH (311 ) and sorbent dosage (1-9 g/l) were studied on the $\mathrm{Na}^{+}$ ion removal, and the best operating conditions for the removal of $\mathrm{Na}^{+}$ion were determined using Design Expert 10 and Central Composite Design (CCD) method.

Then, the solution was filtered using a fiber glass filter for elimination of solid particles. The filtered solution was analyzed to determine the residual $\mathrm{Na}^{+}$. The $\mathrm{pH}$ of each sample was adjusted by hydrochloric acid $(0.1 \mathrm{M})$ and sodium hydroxide $(0.1 \mathrm{M})$. A flame atomic absorption spectroscopy (model Varian AA240, Australia) was applied to specify the residual $\mathrm{Na}^{+}$ion in the samples. In all samples, the $\mathrm{Na}^{+}$ion sorption percentage (R\%) and sorption capacity (q) were determined using equations 1 and 2, respectively.

$$
\begin{aligned}
& R(\%)=\frac{C_{0}-C_{e}}{C_{0}} \times 100 \\
& q=\left(C_{0}-C_{e}\right) \times \frac{V}{M}
\end{aligned}
$$

where, $\mathrm{C}_{\mathrm{o}}$ is the initial sodium concentration and $\mathrm{C}_{\mathrm{e}}$ is the equilibrium sodium concentration after uptake process, $\mathrm{R}$ is the removal efficiency of $\mathrm{Na}^{+}, \mathrm{M}$ is the weight of adsorbent in the solution ( $\mathrm{g}$ ) and $\mathrm{V}$ is the volume of the solution (L).

\section{Results and discussion \\ 3. 1. Determination of the Primary Efficiency of the Three Utilized Adsorbents}

To evaluate the initial performance of the adsorbents, their adsorption efficiency in the removal of sodium ions was studied. To this end, experiments were performed at different contact times. Other conditions were kept constant, including $\mathrm{pH}$ of 7 , temperature of $25^{\circ} \mathrm{C}, \mathrm{Na}^{+}$ion concentration of $900 \mathrm{mg} / \mathrm{L}$, and adsorbent dosage of $5 \mathrm{~g} / \mathrm{L}$. Since these conditions have been used in most previous work to perform the sodium adsorption process, the adsorption experiments were performed under these conditions to compare the three adsorbents. Figure 1 indicates the sodium uptake efficiency from aqueous solution using the eggshell derived $\mathrm{CaO}, \mathrm{CaO} /$ $\mathrm{Fe}_{3} \mathrm{O}_{4}$ composite, and AC prepared by Moringa oleifera plant leaves. As can be seen, the AC with an uptake efficiency of $79 \%$ has the maximum uptake efficiency compared to the other two adsorbents. According to Figure 1, the removal efficiency of $\mathrm{Na}+$ using $\mathrm{AC}$ is about $25 \%$ higher than $\mathrm{CaO} /$ $\mathrm{Fe}_{3} \mathrm{O}_{4}$ and $35 \%$ higher than eggshell derived $\mathrm{CaO}$ and this difference in efficiency is observed at all times. Therefore, the $\mathrm{AC}$ was used for further experiments and to determine the optimal conditions for $\mathrm{Na}^{+}$ion removal.

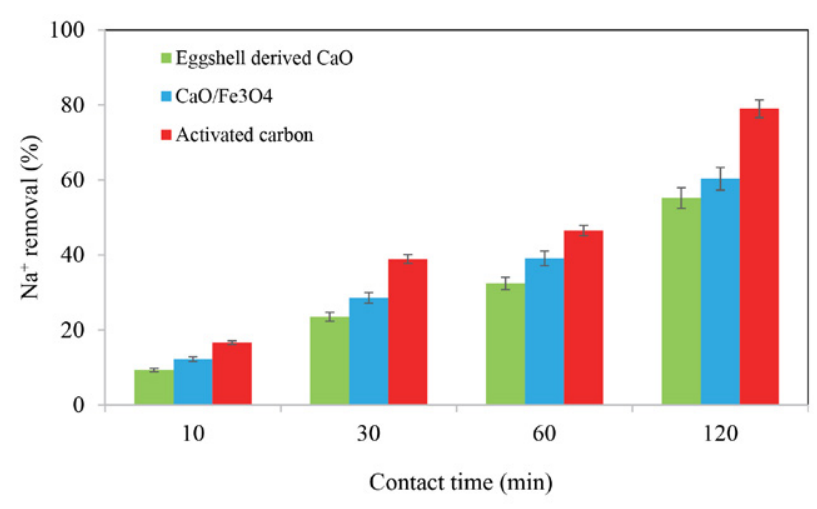

Figure 1. Primary investigations about three studied adsorbents in $10,30,60$, and $120 \mathrm{~min}$ and neutral $\mathrm{pH}$

\section{2. Characteristics of the Adsorbent}

FTIR analysis was used to determine functional groups in the structure of Moringa oleifera leaves-derived $\mathrm{AC}$ as shown in Figure 2-a. These spectra approve the presence of many functional groups and indicate the natural complex of this material. As shown, the absorption peak at $3048 \mathrm{~cm}^{-1}$ is related to the tensile vibration of $\mathrm{OH}$ group in proteins, fatty acids, carbohydrates, and lignin, which are due to its high contents in plant grain as well as N-H tensile bonding in amides. ${ }^{24-25}$ Also, the peak at $2895 \mathrm{~cm}^{-1}$ is related to the $=\mathrm{C}-\mathrm{H}$ bond. ${ }^{23}$ Moreover, the peaks at 795 $\mathrm{cm}^{-1}$ and $926 \mathrm{~cm}^{-1}$ are attributed to the $\mathrm{N}-\mathrm{H}$ and $\mathrm{O}-\mathrm{H}$ functional groups, respectively. Furthermore, the peaks at $1232.8,1396.8,1506$ and $1615.6 \mathrm{~cm}^{-1}$ can be attributed to the $\mathrm{C}-\mathrm{O}, \mathrm{C}-\mathrm{H}, \mathrm{C}=\mathrm{C}$, and $\mathrm{C}=\mathrm{O}$, respectively. ${ }^{24,26-28}$

Also, SEM analysis was applied to characterize the morphology of the Moringa oleifera-derived AC and its image is seen in Figure 2-b. It is obvious that the AC has a relatively porous structure with heterogeneous distribution. Also, some pores are observed on the surface of the adsorbent that include the accessible sites. These pores provide suitable conditions for the uptake of $\mathrm{Na}^{+}$ions from aqueous solution. ${ }^{29}$

Moreover, XRD analysis is used to identify and evaluate the crystalline phases in the adsorbent structure. Generally, materials are classified into different groups of amorphous, semi-crystalline, and crystalline. Figure 2-c shows the XRD pattern of the AC. According to Figure 2-c, the adsorbent shows a long peak at $2 \boldsymbol{\theta}=20^{\circ}$, which is attributed to the crystalline phase of (111) in the AC structure. ${ }^{30,31}$

Besides, BET analysis showed that the specific surface area, pore volume and mean pore diameter of the activated carbon prepared from Moringa oleifera leaves were obtained as $136.25 \mathrm{~m}^{2} / \mathrm{g}, 0.158 \mathrm{~cm}^{3} / \mathrm{g}$, and $55^{\circ} \mathrm{A}$, respectively, which shows that the adsorbent has a significant specific surface area. Also, the mean pore size of the adsorbent indicates that the adsorbent has a mesoporous structure, because the mean pore size is between $2-50 \mathrm{~nm}^{13}$ 

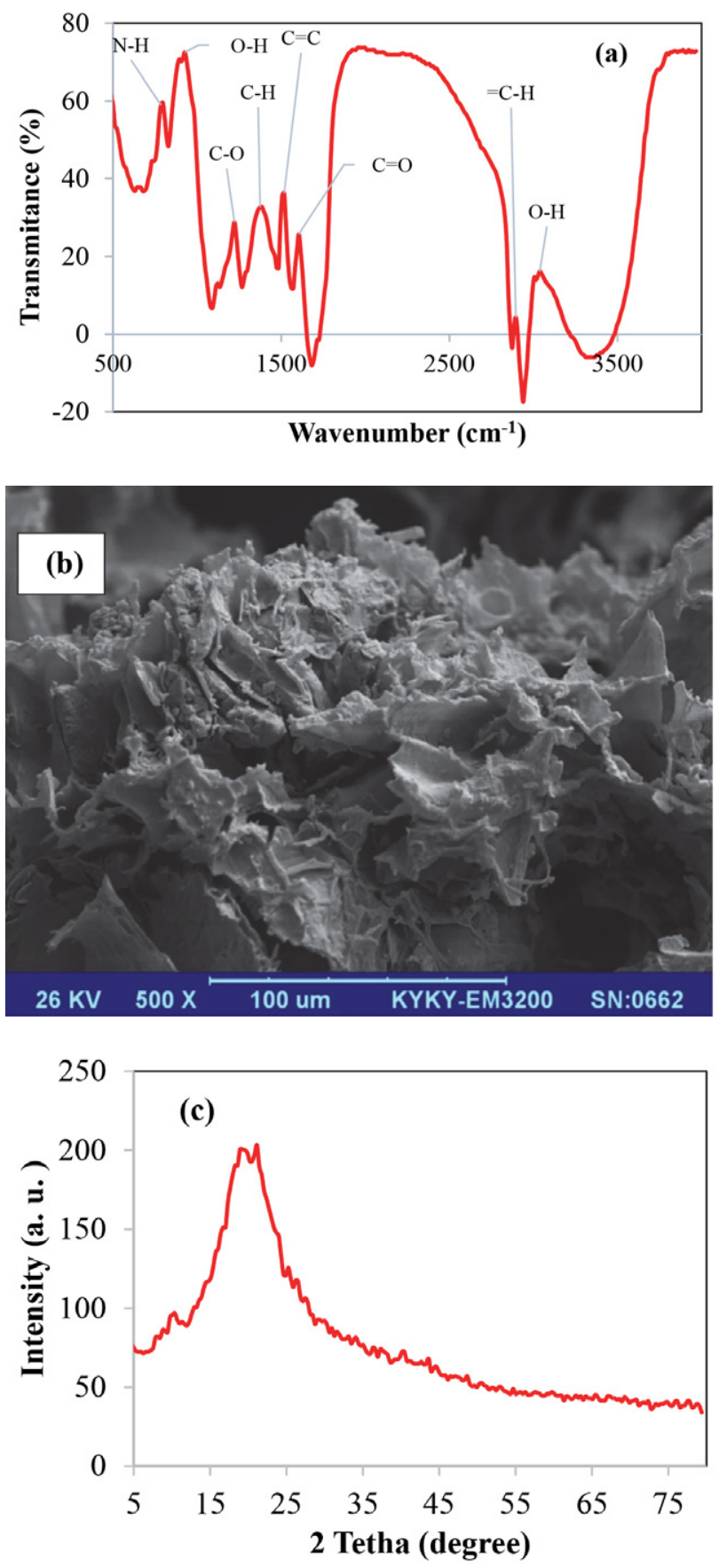

Figure 2. The characteristics of the activated carbon made from $\mathrm{Mo}$ ringa oleifera plant using various analyses, including FTIR (a), SEM (b), and XRD (c).

\section{3. Effective Parameters on the Sorption Process}

The impact of various factors on the sodium ion sorption using the AC is demonstrated in Figure 3. As seen in this Figure, the uptake efficiency of $\mathrm{Na}^{+}$ion increases with increasing $\mathrm{pH}$, contact time, and adsorbent dosage.

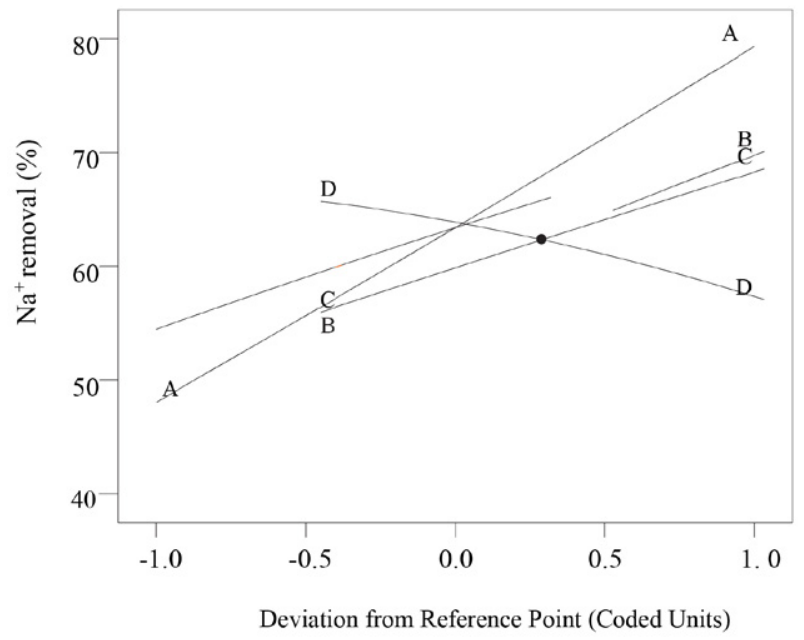

Figure 3. Effective parameters on adsorption process (separately and without any effect on each other) at $\mathrm{pH}$ of 7 , contact time of 45 min, the adsorbent dosage of $5 \mathrm{~g} / \mathrm{L}$, and initial $\mathrm{Na}^{+}$concentration of $900 \mathrm{mg} / \mathrm{l}$.

The impact of $\mathrm{pH}$ and $\mathrm{Na}+$ concentration on the $\mathrm{Na}^{+}$ ion removal efficiency using the AC simultaneously is shown in Figure 4. Other experimental conditions were kept constant, including contact time of $45 \mathrm{~min}$, temperature of $25^{\circ} \mathrm{C}$, and adsorbent dosage of $5 \mathrm{~g} / \mathrm{L}$. According to the results, the sorption efficiency increased with increasing the $\mathrm{pH}$ value from 3 to 11 and the maximum sorption efficiency was obtained at $\mathrm{pH}=11$. The formation of hydroxide ion $\left(\mathrm{OH}^{-}\right)$and its bonding to the surface of the adsorbent makes the adsorbent surface negatively charged and the adsorbent ability increases in the sorption of cations. The reason of reduction in the adsorption efficiency in acidic $\mathrm{pH}$ might be that the increase in hydrogen ion production creates a positive charge on the adsorbent surface (protonation of the adsorbent). ${ }^{32}$ In other words, the $\mathrm{pH}$ of zero point charge (isoelectric $\mathrm{pH}$ ) plays an important role in the adsorption process. Since this $\mathrm{pH}$ was obtained about 6.5 for the studied adsorbent, the Moringa oleifera adsorbent surface will be negatively charged in higher $\mathrm{pH}$ values and consequently, a strong electrostatic attraction will form between the surface groups and available cations $\left(\mathrm{Na}^{+}\right)$. Therefore, the adsorption efficiency was increased and the maximum sodium ion adsorption efficiency was obtained $95.53 \%$, but in $\mathrm{pH}$ values less than the isoelectric point, the adsorbent surface is positively charged and forms a stable electrostatic repulsion force, which reduces the sorption of $\mathrm{Na}^{+}$ions. Another reason for the reduction in $\mathrm{Na}^{+}$ion adsorption in acidic conditions is the strong competition between the hydrogen ion $\left(\mathrm{H}^{+}\right)$and positively charged sodium ions to be adsorbed on the adsorbent surface, which decreases the adsorption efficiency.

Therefore, $\mathrm{pH}=11$ was selected as the optimum $\mathrm{pH}$ and further adsorption experiments were carried out at 
Design-Expertø Software Factor Coding: Actual - Design Points - Design Poin

प3

$\mathrm{X} 1=\mathrm{A}: \mathrm{pH}$ X2=D: Na concentration

Actual Factors
B. Tume $=45$ C: adsorbent $=5$
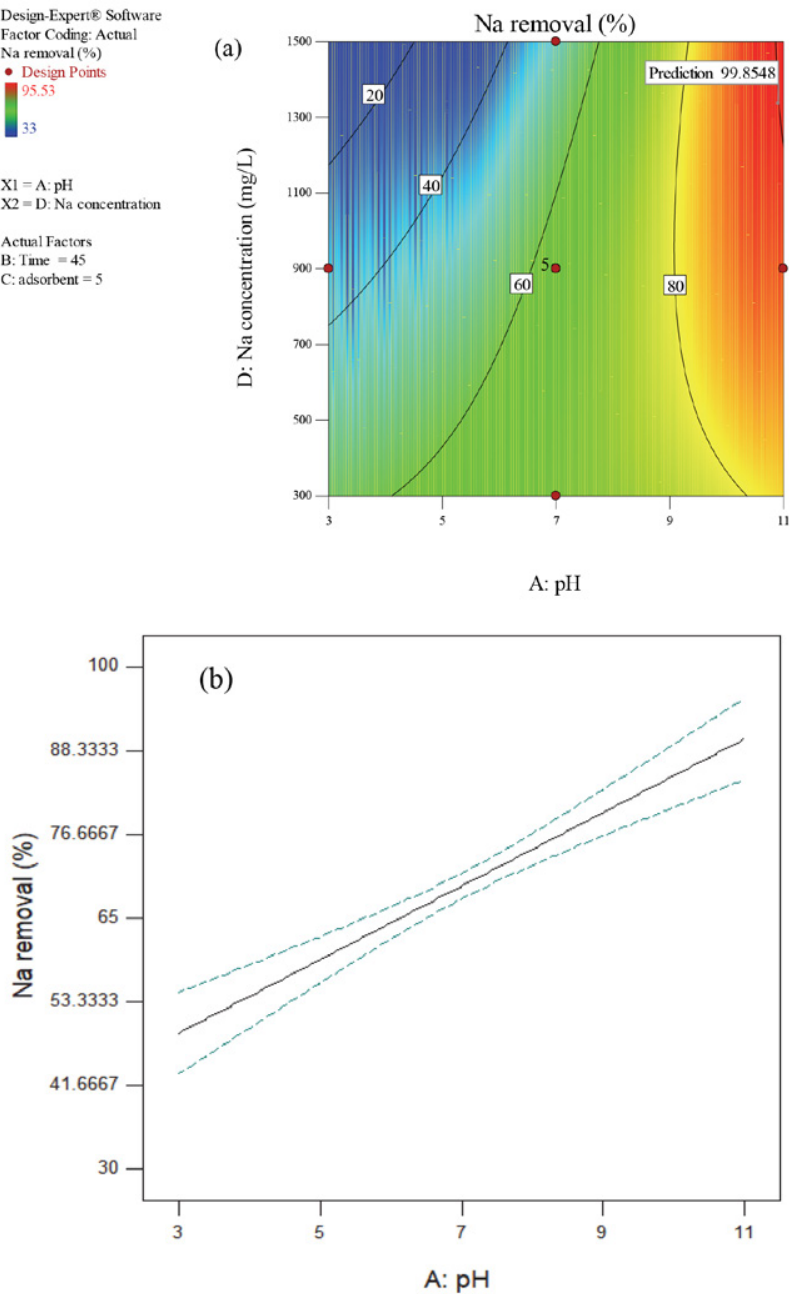

Figure 4. The effect of $\mathrm{pH}$ on the sodium ion adsorption from an aqueous solution using the $\mathrm{AC}$ in different concentrations of sodium ion

this $\mathrm{pH}$ value. Figure 5 shows the effect of contact time on the sorption efficiency of sodium using the activated carbon, in different sodium concentrations. Experiments were carried out at $\mathrm{pH}=11$ (the optimum value) and adsorbent dosage of $3.5 \mathrm{~g} / \mathrm{L}$. As can be seen, increasing the contact time has increased sodium adsorption efficiency and then it has reached the equilibrium value. Changes in the adsorbent capacity, when contact time increases, indicated that in the first $45 \mathrm{~min}$, the intensity of changes was high and then the adsorption trend became constant. Rapid enhancement of adsorption capacity in the early stages of the adsorption process was due to the high number of active sites for sodium adsorption on the adsorbent surface. When the process continued, the access of ions to the active sites was reduced, and eventually, the adsorption process reached an equilibrium at a specific time. After the equilibrium, there might be negligible changes in the adsorption capacity. Therefore, the optimum contact time was attained $47 \mathrm{~min}$.
Design-Expent» Softwar Factor Coding: Actual Na removal (\%)
- Desion Points

- Design Poims
95.53

33

$\mathrm{X} 1=\mathrm{B}:$ Time $\mathrm{X}_{2}=\mathrm{D}$ : Na concentration Actual Factors A: $\mathrm{pH}=11$
C: adsorbent -5
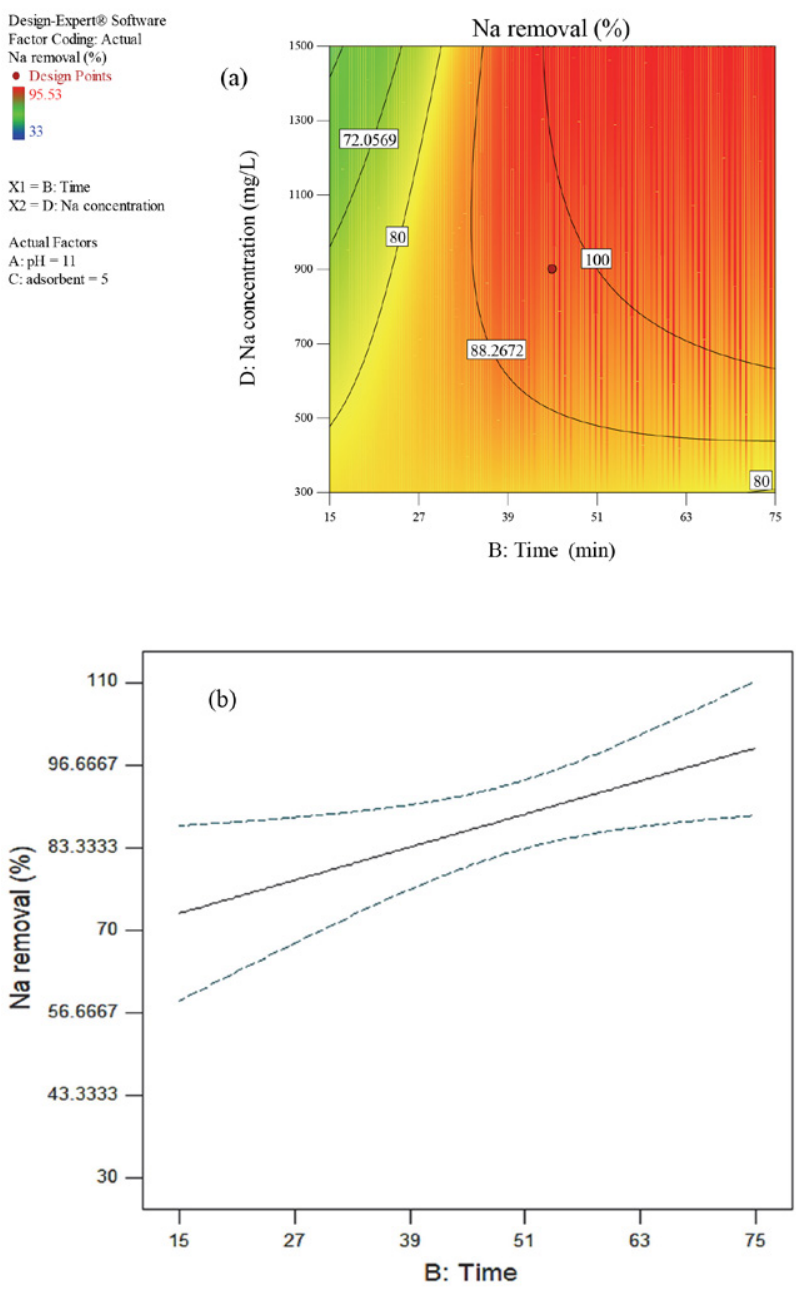

Figure 5. The effect of contact time on sodium adsorption from aqueous solution using the $\mathrm{AC}$ in different sodium ion concentrations
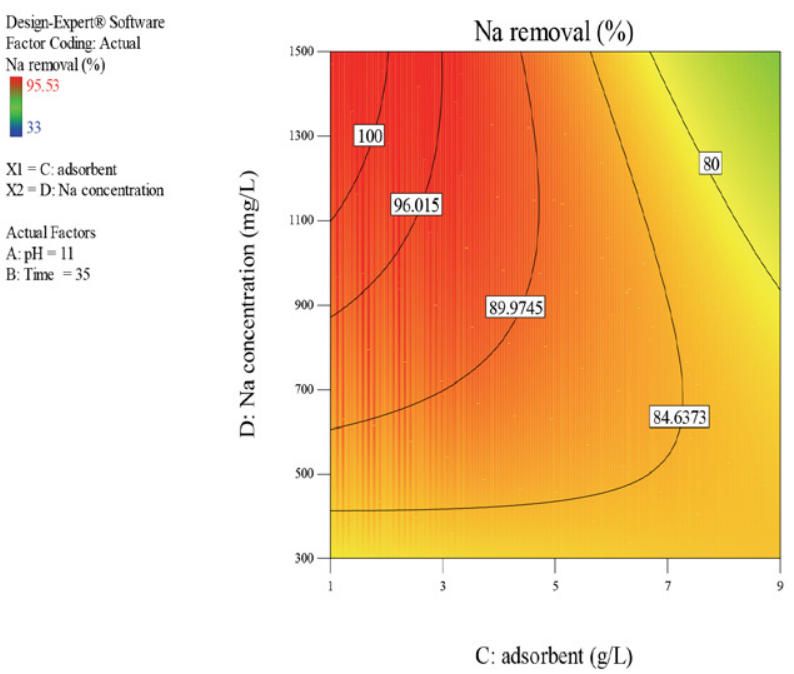

Figure 6. Effect of adsorbent dose on sodium adsorption from aqueous solutions in different concentrations of sodium ion 
The effect of adsorbent dosage on sodium ion adsorption efficiency is indicated in Figure 6. According to the results, the removal efficiency increases with increasing adsorbent dosage, which is due to the enhancement of active sites on the adsorbent surface. ${ }^{19}$ The research results indicated that the enhancement of the initial concentration of sodium ion decreases the adsorption efficiency, which is due to the saturation of the adsorbent surface in high sodium concentrations.

Nowadays, using statistical design and presenting logical correlations between variables is widely used in many research fields. Using statistical methods decreases the number of experiments and as a result, the costs and manpower. ${ }^{33-34}$ Utilization of statistical method in this study resulted in the following equation that shows the empirical correlation between experimental variables and efficiency percentage in a coded form:

$$
\begin{aligned}
& \mathrm{Na}^{+} \text {removal }=63.4+15.63 A+8.47 B \\
& \quad+6.51 C-4.47 D+0.95 A B-5.45 A C \\
& \quad+4.65 A D-0.51 B C+5.47 B D-2.3 C \\
& \quad+0.3 A^{2}-0.46 B^{2}-0.07 C^{2}
\end{aligned}
$$

$\mathrm{X}_{1}, \mathrm{X}_{2}, \mathrm{X}_{3}$, and $\mathrm{X}_{4}$ show the $\mathrm{pH}$, contact time, adsorbent dosage, and pollutant concentration, respectively. The effect of studied parameters on the sorption efficiency of sodium ion was investigated by analysis of variance (ANOVA) and the outcomes are presented in Table 1.

The values of $R^{2}=0.9950$ and Adj $R^{2}=0.9834$ verifies that sodium adsorption by the activated carbon made from Moringa oleifera can be well explained by the de- signed model. Also, the F-value was obtained 85.88, which shows the ability of the selected model in data analysis. The low value of $\mathrm{CV}$ also verifies that this model is suitable for interpretation of the studied process. Adequate precision is the parameter that indicates the ratio of signal to noise; if its value is more than 4 , it shows an appropriate relation between the experimental data and the calculated values (desirability). In this study, the mentioned parameter was obtained 38.36. Then, the influence of the effective parameters on the uptake process of $\mathrm{Na}^{+}$was studied using the analysis of variance. The results indicated that $\mathrm{X}_{1}, \mathrm{X}_{2}, \mathrm{X}_{3}, \mathrm{X}_{4}, \mathrm{X}_{1} \mathrm{X}_{3}, \mathrm{X}_{1} \mathrm{X}_{4}, \mathrm{X}_{2} \mathrm{X}_{4}$, and $\mathrm{X}_{3} \mathrm{X}_{4}$ parameters had significant effect $(\mathrm{P}<0.05)$ on sodium adsorption. ${ }^{34}$ The sequence of two parameters of the sum of squares and F-value was pollutant concentration $<$ adsorbent dosage $<$ contact time $<\mathrm{pH}$ that indicates the maximum effect of $\mathrm{pH}$ and the minimum effect of pollutant concentration on the $\mathrm{Na}^{+}$removal. Investigation of the normality of the studied data and the residuals, as two important assumptions, is essential for using this statistical model. The normal probability curve shows the normal distribution of data around a mean value and the linearity of this curve shows that experimental data are normal.

The R-squared value was obtained to be 0.942 from the normal probability curve. The test of normality of output data and residuals are shown in Figure 7.

Figure 7 shows the actual (experimental) and the predicted values of sodium adsorption by Design Expert 10 in 21 different runs. The high level of conformity of the actual value with the predicted one indicates the excellent ability of the software in the prediction of the experiment results in different runs.

Table 1. Results of the analysis of variance for the studied model

\begin{tabular}{lccccc}
\hline \multicolumn{5}{c}{ ANOVA for Response Surface Quadratic model } \\
\hline Source & Sum of & & Mean & F & p-value \\
Squares & df & Square & Value & \\
\hline Model & 4860.52 & 14 & 347.18 & 85.88 & $<0.0001$ \\
A-pH & 1955.00 & 1 & 1955.00 & 483.57 & $<0.0001$ \\
B-Time & 573.93 & 1 & 573.93 & 141.96 & $<0.0001$ \\
C-adsorbent & 677.69 & 1 & 677.69 & 167.63 & $<0.0001$ \\
D-Na ${ }^{+}$concentration & 159.85 & 1 & 159.85 & 0.90 & $<0.0008$ \\
$\mathrm{AB}$ & 3.62 & 1 & 3.62 & 0.90 & 0.3806 \\
$\mathrm{AC}$ & 237.29 & 1 & 237.29 & 58.69 & 0.0003 \\
$\mathrm{AD}$ & 86.63 & 1 & 86.63 & 21.43 & 0.0036 \\
$\mathrm{BC}$ & 2.09 & 1 & 2.09 & 0.52 & 0.4991 \\
$\mathrm{BD}$ & 119.52 & 1 & 119.52 & 29.56 & 0.0016 \\
$\mathrm{CD}$ & 42.46 & 1 & 42.46 & 10.50 & 0.0177 \\
$\mathrm{~A}^{2}$ & 2.47 & 1 & 2.47 & 0.61 & 0.4641 \\
$\mathrm{~B}^{2}$ & 5.31 & 1 & 5.31 & 1.31 & 0.2954 \\
$\mathrm{C}^{2}$ & 0.13 & 1 & 0.13 & 0.032 & 0.8649 \\
$\mathrm{D}^{2}$ & 23.13 & 1 & 23.13 & 5.72 & 0.0539 \\
$\mathrm{Residual}$ & 24.26 & 6 & 4.04 & & 0.9462 \\
$\mathrm{R}^{2}$ & 0.9950 & $\mathrm{R}^{2}$-Adjusted & 0.9834 & $\mathrm{R}^{2}$-Predicted & \\
\hline
\end{tabular}

Yao et al.: Selective Removal of Sodium Ions from Aqueous Media ... 

Design-Expertæ Software
Na removal Studentized residuals recommended Color points by vahe of Na removal: 95.5 Design-Expert8 Software
a removal
tudentized residuals recommended
Color points by value of
a removal:
95.53
33
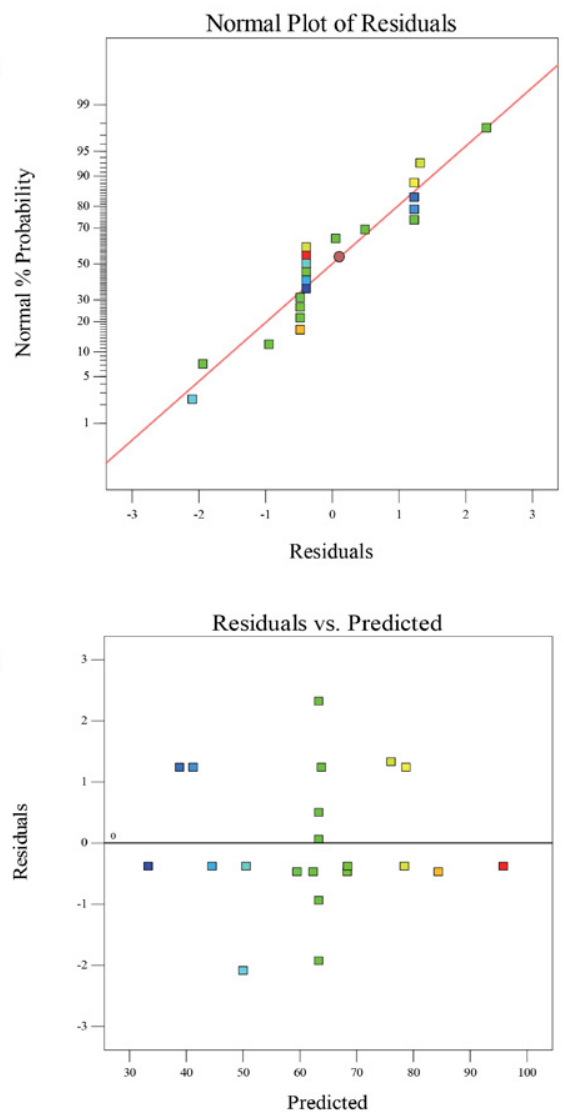

Figure 7. The normality of primary data and residuals
The very high value of R-square confirms the prediction ability of the $\mathrm{Na}^{+}$ion adsorption process in the studied system. Then, the real (experimental) values are plotted versus the predicted values and compared with each other. As predicted, the resulted R-square from regression was very close to 1 .

\section{4. Prediction of Adsorption Process by the Software}

In Table 2, independent variables and the range and levels of experimental values are presented for activated carbon as an adsorbent in the removal of $\mathrm{Na}^{+}$ions. In this study, the total number of experiments in the CCD design method was 21 . Furthermore, the sorption efficiency of sodium ion in different experimental conditions was reported.

Figure 8(a) shows the actual and predicted values of sodium ion removal percentage using activated carbon in various experiments. The predicted values of sodium ion removal efficiency are extracted from Figure 8(a) and then reported in Table 2. As reported in Table 2, the maximum removal efficiency of $\mathrm{N}^{+}$ion was achieved $95.91 \%$. Also, the value of $\mathrm{R}^{2}$ coefficient was achieved 0.9975 , which indicates a good ability of the model in the prediction of data.

Figure 8(b) also shows the experimental outcomes versus the predicted ones by Design Expert 10. As seen in this figure, the $\mathrm{R}^{2}$ value of 0.9462 was achieved for the prediction, which verifies the results obtained in the previous stage.

Table 2. The impact of independent variables on the removal efficiency of sodium using AC. Experimental design was done by CCD method

\begin{tabular}{|c|c|c|c|c|c|c|}
\hline Run & A: pH & $\begin{array}{l}\text { B: Time } \\
(\min )\end{array}$ & $\begin{array}{l}\mathrm{C}: \text { adsorbent } \\
\text { dose }(\mathrm{g} / \mathrm{L})\end{array}$ & $\begin{array}{l}\mathrm{D}: \mathrm{Na}^{+} \text {conc. } \\
(\mathrm{mg} / \mathrm{l})\end{array}$ & $\begin{array}{l}\mathrm{Na}^{+} \text {removal } \\
(\%)\end{array}$ & $\begin{array}{c}\text { Predicted value } \\
\text { of } \mathrm{Na}+\text { removal (\%) }\end{array}$ \\
\hline 1 & 5 & 60 & 7 & 1200 & 59.11 & 59.58 \\
\hline 2 & 11 & 45 & 5 & 900 & 95.53 & 95.91 \\
\hline 3 & 7 & 45 & 9 & 900 & 77.45 & 76.12 \\
\hline 4 & 5 & 60 & 3 & 1200 & 42.54 & 41.3 \\
\hline 5 & 3 & 45 & 5 & 900 & 33 & 33.38 \\
\hline 6 & 7 & 45 & 5 & 900 & 63.45 & 63.39 \\
\hline 7 & 9 & 60 & 7 & 600 & 84 & 84.47 \\
\hline 8 & 7 & 45 & 5 & 900 & 65.71 & 63.39 \\
\hline 9 & 7 & 75 & 5 & 900 & 78.11 & 78.49 \\
\hline 10 & 7 & 45 & 5 & 900 & 63.89 & 63.39 \\
\hline 11 & 7 & 45 & 5 & 1500 & 50.23 & 50.61 \\
\hline 12 & 9 & 30 & 7 & 1200 & 61.94 & 62.41 \\
\hline 13 & 7 & 45 & 5 & 900 & 62.45 & 63.39 \\
\hline 14 & 7 & 15 & 5 & 900 & 44.23 & 44.61 \\
\hline 15 & 7 & 45 & 5 & 300 & 68.11 & 68.49 \\
\hline 16 & 5 & 30 & 7 & 600 & 67.95 & 68.42 \\
\hline 17 & 5 & 30 & 3 & 600 & 40.12 & 38.88 \\
\hline 18 & 9 & 30 & 3 & 1200 & 65.11 & 63.87 \\
\hline 19 & 7 & 45 & 5 & 900 & 61.46 & 63.39 \\
\hline 20 & 9 & 60 & 3 & 600 & 80 & 78.76 \\
\hline 21 & 7 & 45 & 1 & 900 & 48 & 50.09 \\
\hline
\end{tabular}




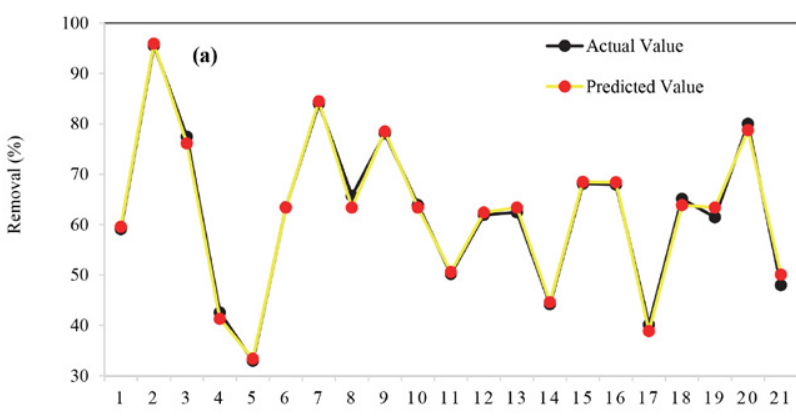

Run

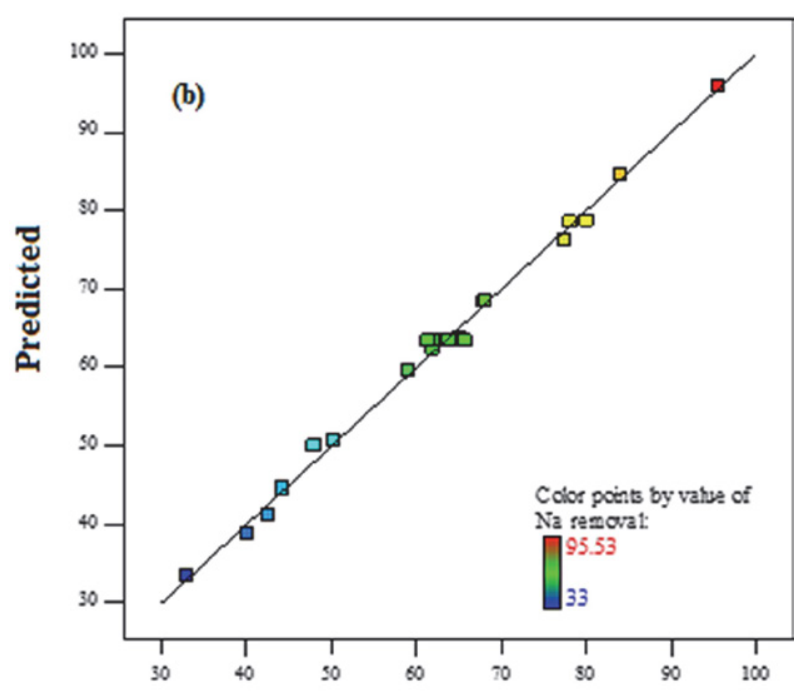

Actual

Figure 8. Predicted and real values of efficiency in different runs of the experiment (a) the experimental results versus the predicted results by the software (b)

\section{5. Optimization of Sodium Adsorption Process}

Optimization of process conditions is necessary for any statistical model. To do this, Genetic Algorithm (GA) was applied for the optimization of $\mathrm{Na}^{+}$uptake process. In this model, the best conditions for eliminating $\mathrm{Na}^{+}$ions were determined. To optimize the uptake process, the studied parameters were selected in the range of their maximum and minimum values. In fact, the algorithm genetic method is capable of interpolating data and can optimize results. Therefore, interpolation between data is a prominent feature of the genetic algorithm method compared to the CCD method. The target variable $\left(\mathrm{Na}^{+}\right.$removal efficiency (\%)) was considered in the maximum value. The purpose of using the GA method was to determine the best conditions of the $\mathrm{Na}^{+}$removal and uses the results of the CCD method. After determining the optimal conditions by the CCD method, the data were entered into the software to optimize the parameters and to do this, $\mathrm{Na}^{+}$removal efficiency was considered as the response (target function). ${ }^{35}$ It should be noted that before optimizing the effective parameters in the adsorption process, the studied algorithm has determined some points (Generation) in the first step, and then, in the next step, it looks for the generation that has the minimum error. Eventually, it optimizes the parameters of the generation with the minimum possible error. The response of the genetic algorithm with the best efficiency and the mean efficiency of sodium removal in different generations are presented in Figure 9. As can be seen, when generations increase, the conformity of these two figures increases as well, so that in the generation $=135$, the best and the mean efficiencies are matched and there will be no mutation or sudden change on it. Figure 9 is plotted to ensure more reliability of the first stage which is to find the most accurate generation. Here, the distances between all individual generations are presented. As it was expected, when the number of generations increases, the mean distance between them decreases, and in generation $=135$, this distance is almost zero. After determining the best generation, the optimum effective factors were determined in the sodium adsorption process. According to Figure 9, the optimum values of $\mathrm{pH}$, contact time, adsorbent dosage, and $\mathrm{Na}^{+}$ion concentration were obtained 10.918, $46.967 \mathrm{~min}, 3.516 \mathrm{~g} / \mathrm{L}$, and $939.921 \mathrm{mg} / \mathrm{L}$, respectively. Then, to check the accuracy of the genetic algorithm in the optimization of the conditions, all the results obtained in the laboratory (real conditions) were repeated and similar results were obtained. In the optimum conditions, the removal efficiency of $\mathrm{Na}^{+}$ion was obtained $94.23 \%$ by the genetic algorithm.

\section{6. Adsorption Isotherms}

Adsorption isotherms are used to describe the equilibrium relationship between adsorbent and adsorbate in an aqueous solution. Also, they are the main factors in the design of sorption systems. ${ }^{36}$ The most common isotherms are Freundlich and Langmuir isotherms. The Freundlich equilibrium isotherm is based on the multilayer and heterogeneous adsorption on the adsorbent. The linear form of this equation is expressed below: ${ }^{37}$

$$
\ln q_{e}=\ln k_{F}+\frac{1}{n} \ln C_{e}
$$

where, $\mathrm{k}_{\mathrm{F}}\left(\mathrm{mg} / \mathrm{g}(\mathrm{L} / \mathrm{mg})^{1 / \mathrm{n}}\right)$ and $\mathrm{n}$ are the Freundlich constants: ${ }^{38}$

The Langmuir isotherm model assumes monolayer sorption on a surface containing a limited number of uniform energy adsorption sites. ${ }^{36}$ This model also states that adsorption only occurs on homogeneous sites, without any action between the adsorbate and adsorbent molecules. ${ }^{39}$ The linear form of the Langmuir model is expressed as follows:

$$
\frac{C_{e}}{q_{e}}=\frac{C_{e}}{q_{o}}+\frac{1}{k_{L} q_{o}}
$$



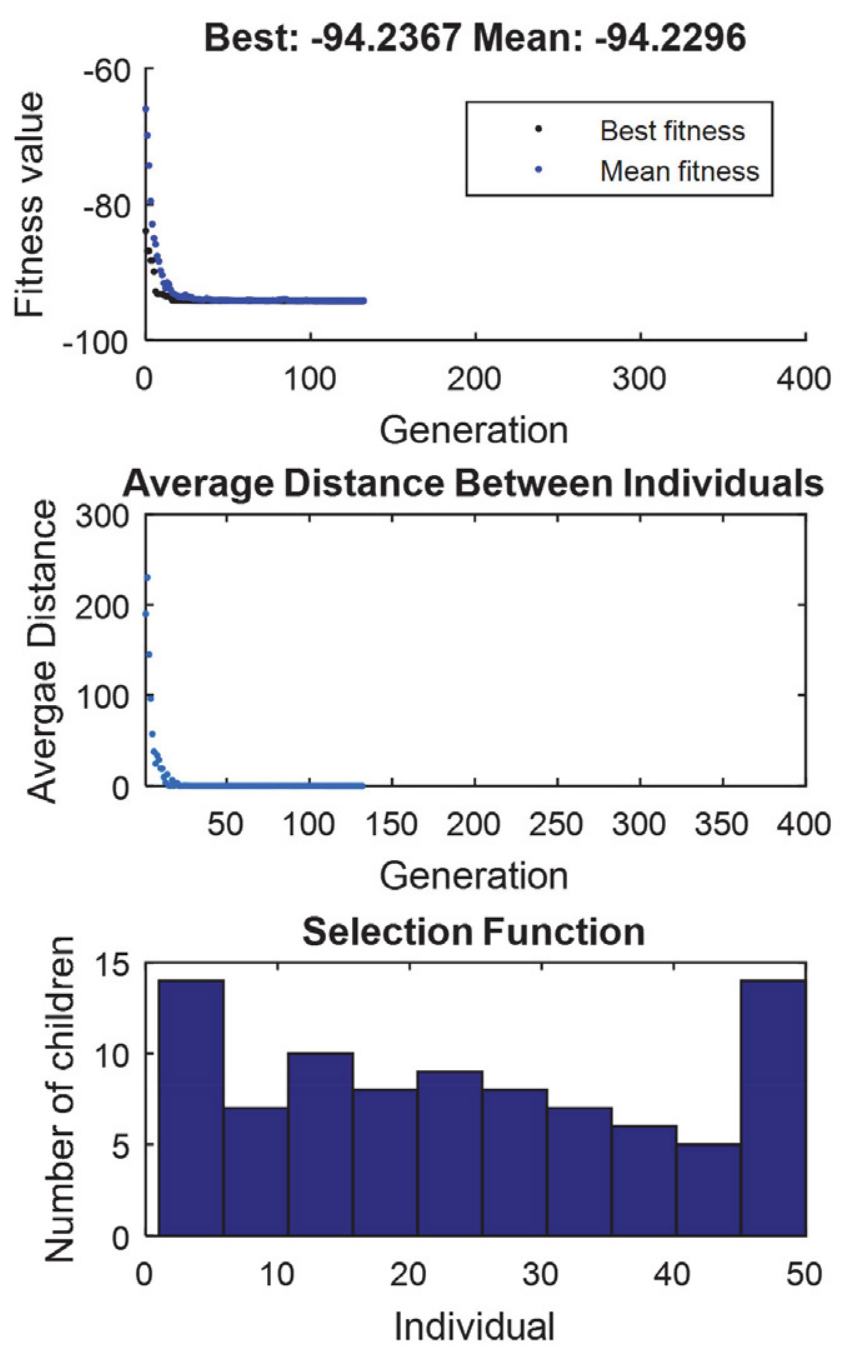

Figure 9. The optimization steps of adsorption parameters using genetic algorithm

where, $\mathrm{k}_{\mathrm{L}}$ is the Langmuir constant $(\mathrm{L} / \mathrm{mg})$ and $\mathrm{q}_{\mathrm{o}}$ is the maximum adsorbed amount per gram of the adsorbent $(\mathrm{mg} / \mathrm{g}), \mathrm{C}_{\mathrm{e}}$ is the equilibrium concentration of the adsorbate $(\mathrm{mg} / \mathrm{L})$, and $\mathrm{q}_{\mathrm{e}}$ is the initial amount of adsorbate at equilibrium $(\mathrm{mg} / \mathrm{g})$.

The value of the parameters of Langmuir and Freundlich models are presented in Table 3. Also, the plots of the Langmuir and Freundlich models for the sodium sorption process are shown in Figure 10. Considering the results, the maximum uptake capacity by the Langmuir model was determined $249.67 \mathrm{mg} / \mathrm{g}$, which was a significant value. Also, the correlation coefficient for the Langmuir model $\left(\mathrm{R}^{2}=1\right)$ was greater than the Freundlich model $\left(\mathrm{R}^{2}=\right.$ 0.993). Therefore, in all three studied temperatures, the Langmuir model could better describe the equilibrium behavior of the sorption process, and the sorption process of sodium ion took place as monolayer on the homogeneous
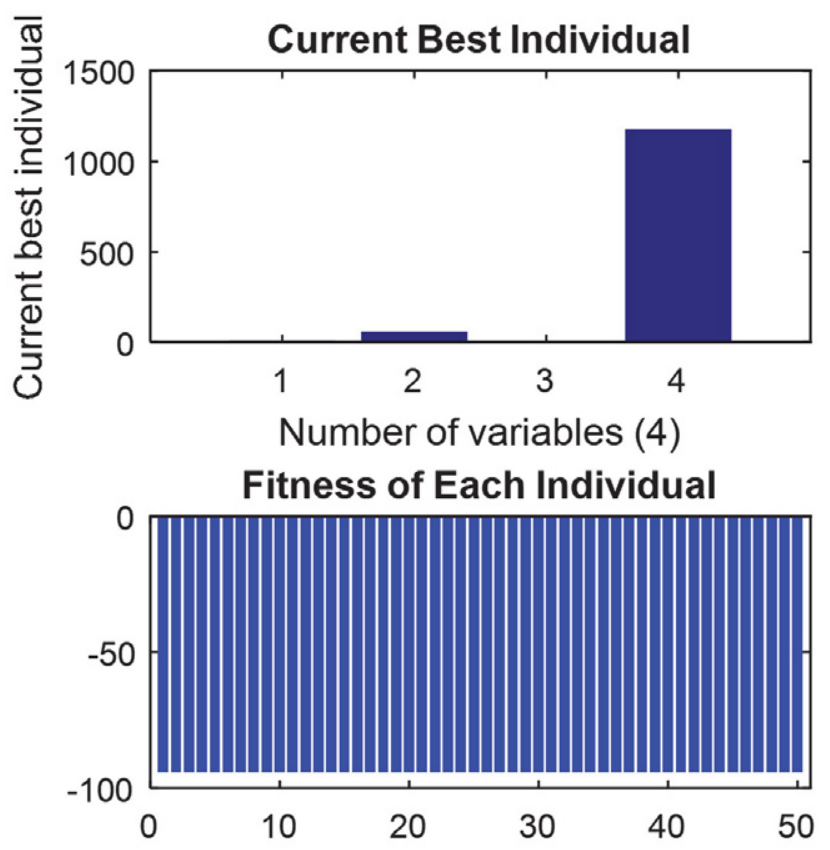

surface of the adsorbent. The values of $\mathrm{R}_{\mathrm{L}}$ in the Langmuir model is between 0 and 1 and the values of the Freundlich constant $(1 / \mathrm{n})$ were less than 1 , which show the sorption of $\mathrm{Na}^{+}$ion is favorable and physical. Moreover, the Langmuir constant $\left(\mathrm{K}_{\mathrm{L}}\right)$ and the Freundlich constant $\left(\mathrm{K}_{\mathrm{F}}\right)$ were obtained $0.251 \mathrm{~L} / \mathrm{mg}$ and $223.22(\mathrm{mg} / \mathrm{g})(\mathrm{L} / \mathrm{mg})^{1 / \mathrm{n}}$, respectively.

Table 3. Constants and parameters of the Langmuir and Freundlich isotherm models for the sorption of sodium ion from aqueous solution using activated carbon

\begin{tabular}{lll}
\hline Isotherm & parameter & value \\
\hline \multirow{3}{*}{ Langmuir } & $\mathrm{q}_{0}(\mathrm{mg} / \mathrm{g})$ & 249.67 \\
& $\mathrm{~K}_{\mathrm{L}}(\mathrm{L} / \mathrm{mg})$ & 0.251 \\
Freundlich & $\mathrm{R}^{2}$ & 1 \\
& $\mathrm{~K}_{\mathrm{F}}(\mathrm{mg} / \mathrm{g})(\mathrm{L} / \mathrm{mg})^{1 / \mathrm{n}}$ & 223.22 \\
& $\mathrm{n}$ & 59.95 \\
& $\mathrm{R}^{2}$ & 0.993 \\
\hline
\end{tabular}

\section{7. Adsorption Process Kinetics}

It is necessary to study the process kinetics for the investigation of the effective parameters on the sorption rate. The sorption process may occur in several stages with different rates. Here, we just discuss the two main and common kinetic models that are quasi-first-order (QFO) and quasi-second-order (QSO) kinetic models. ${ }^{19}$

The QFO kinetic model is based on the sorption capacity in adsorption of a pollutant and is used when the 

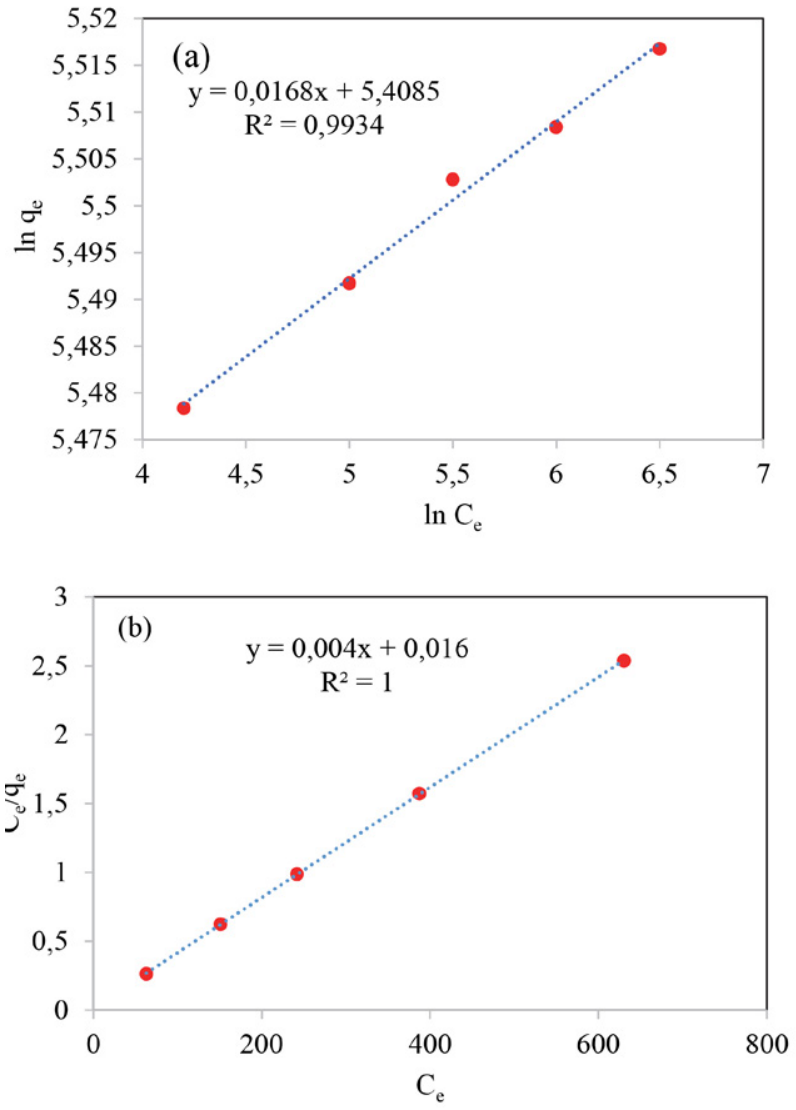

Figure 10. The Freundlich (a) and Langmuir (b) equilibrium isotherms

adsorption follows the diffusion mechanism through a boundary layer. The QFO model is described as follows: ${ }^{17}$

$$
\ln \left(q_{e}-q_{t}\right)=\ln q_{e}-k_{1} t
$$

Where, $\mathrm{q}_{\mathrm{e}}$ and $q_{t}$ are the uptake capacity at equilibrium and at time $t$ in terms of $\mathrm{mg} / \mathrm{g}$ and $\mathrm{k}_{1}$ is the QFO kinetic constant $\left(\mathrm{min}^{-1}\right)$.

Also, the linear form of the QSO kinetic model is define below: ${ }^{17}$

$$
\frac{t}{q_{t}}=\frac{1}{k_{2} q_{e}{ }^{2}}+\frac{1}{q_{e}} t
$$

The values obtained from the kinetic parameters of sodium adsorption on Moringa oleifera-derived AC are listed in Table 4. The results of kinetic models are also displayed in Figure 11. It can be seen that the correlation coefficient $\left(\mathrm{R}^{2}\right)$ for the QSO kinetic model is higher than the QFO kinetic model and is around 1, therefore sodium sorption by the AC follows the QSO kinetic model. Furthermore, the calculated values of uptake capacity $\left(\mathrm{q}_{\mathrm{e} \text { cal }}\right)$ follows the QSO kinetic model. ${ }^{17}$ Therefore, the QSO kinetic model was better fitted with the experimental data. Also, the constant values of the QFO and QSO models were determined $0.128 \mathrm{~L} / \mathrm{mg}$ and $0.000463 \mathrm{~L} / \mathrm{mg}$, respectively.
Table 4. Constants and parameters of the QFO and QSO kinetic models for the sorption of sodium ion from aqueous solution using activated carbon

\begin{tabular}{lll}
\hline model & parameter & value \\
\hline \multirow{2}{*}{ QFO } & $\mathrm{q}_{\mathrm{e}, \mathrm{cal}}(\mathrm{mg} / \mathrm{g})$ & 559.6 \\
& $\mathrm{~K}_{1}(\mathrm{~L} / \mathrm{mg})$ & 0.128 \\
& $\mathrm{R}^{2}$ & 0.8797 \\
QSO & $\mathrm{q}_{\mathrm{e}, \mathrm{cal}}(\mathrm{mg} / \mathrm{g})$ & 286.98 \\
& $\mathrm{~K}_{2}(\mathrm{~L} / \mathrm{mg})$ & 0.000463 \\
& $\mathrm{R}^{2}$ & 0.9959 \\
\hline
\end{tabular}
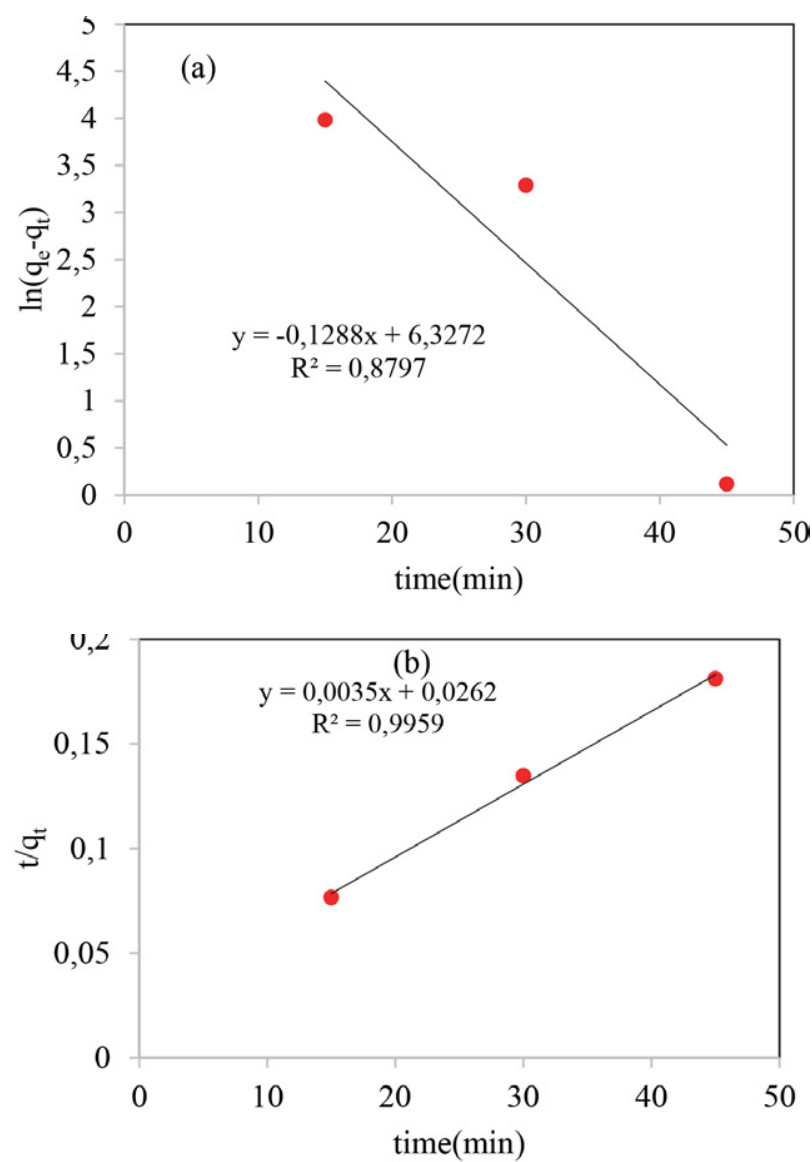

Figure 11. QFO (a) and QSO (b) kinetic models

\section{8. Thermodynamic Study}

The thermodynamic parameters provide information about the spontaneity of the sorption process and an increase or decrease of randomness at the interface of solid-liquid. Also, they determine whether a sorption process is exothermic or endothermic. ${ }^{40,41}$ Three main thermodynamic parameters should be determined to study the thermodynamics of the uptake process. These three parameters are changes of enthalpy $\left(\Delta \mathrm{H}^{\circ}\right)$, Gibbs free energy $\left(\Delta \mathrm{G}^{\circ}\right)$, and entropy $\left(\Delta \mathrm{S}^{\circ}\right)$. The values of $\Delta \mathrm{H}^{\circ}$ and $\Delta \mathrm{S}^{\circ}$ are obtained from the slope and intercept of the following equation: ${ }^{42,43}$ 


$$
\begin{gathered}
\ln \boldsymbol{k}_{c}=\frac{\Delta S^{o}}{R}-\frac{\Delta H^{o}}{R T} \\
K_{c}=\frac{q_{e}}{C_{e}}
\end{gathered}
$$

Where, $\mathrm{R}$ is the global gas constant $(8.314 \mathrm{~J} / \mathrm{mol} \mathrm{K})$ and $\mathrm{K}_{\mathrm{c}}(\mathrm{L} / \mathrm{g})$ is the ratio of the adsorbed material on the adsorbate $(\mathrm{mg} / \mathrm{g})$ to the residual material in the solution $(\mathrm{mg} / \mathrm{L})$. The values of $\Delta \mathrm{G}^{\circ}$ is calculated from the following equation:

$$
\Delta G^{o}=-R T \ln K_{c}
$$

Generally, the negative values of $\Delta \mathrm{G}^{\circ}$ show that the sorption process is spontaneous. The negative values of $\Delta \mathrm{H}^{\circ}$ show that the sorption process is exothermic and also it is favorable at lower temperatures.

The negative values of $\Delta S^{\circ}$ indicate that the efficiency decreases as the temperature increases at the solid-liquid interface during the sorption process and it is vice versa for positive values. ${ }^{44,45}$

The values of thermodynamic parameters for the sodium ion adsorption using the $\mathrm{AC}$ are presented in Table 5. The experiments were done in the initial sodium concentration of $100 \mathrm{mg} / \mathrm{L}$ and temperatures of $20-50^{\circ} \mathrm{C}$. It is observed in Table 5 that the values of $\Delta \mathrm{H}^{\circ}$ and $\Delta \mathrm{S}^{\circ}$ are both negative and are -147 and $-0.455(\mathrm{~kJ} / \mathrm{mol})$, respectively. Also, the values of $\Delta \mathrm{G}^{\circ}$ for temperatures of 20,35 , and 50 ${ }^{\circ} \mathrm{C}$ are $-16.208,-4.849$, and $-2.67(\mathrm{~kJ} / \mathrm{mol})$, respectively. Moreover, the study of the thermodynamic parameters for the sodium ion adsorption using the AC showed that $\Delta \mathrm{H}^{\circ}$ had a negative value, which shows the $\mathrm{Na}^{+}$uptake process is exothermic, it also implies that the uptake process is more favorable in lower temperatures. Furthermore, the negative value of $\Delta S^{\circ}$ is an indication of the reduction in efficiency and degree of freedom at the solid-liquid interface during the uptake process. Besides, the negative values of $\Delta \mathrm{G}^{\circ}$ indicate that the $\mathrm{Na}^{+}$uptake process is spontaneous. ${ }^{39}$

Table 5. Thermodynamic parameters for the sorption process of sodium ion from aqueous solution using activated carbon

\begin{tabular}{lccc}
\hline $\begin{array}{l}\text { Temperature } \\
\left({ }^{\circ} \mathbf{C}\right)\end{array}$ & $\begin{array}{c}-\Delta \mathbf{G}^{\mathbf{o}} \\
(\mathbf{k J} / \mathbf{m o l})\end{array}$ & $\begin{array}{c}\left.\Delta \mathbf{H}^{\mathbf{0}}\right) \\
(\mathbf{k J} / \mathbf{m o l}\end{array}$ & $\begin{array}{c}\Delta \mathbf{S}^{\mathbf{o}} \\
(\mathbf{k J} / \mathbf{m o l ~ K})\end{array}$ \\
\hline 293 & -16.208 & -147 & -0.455 \\
308 & -4.849 & & \\
323 & -2.67 & & \\
\hline
\end{tabular}

\section{9. Final Comparison of the Adsorbents}

After determining the optimal conditions for the removal of $\mathrm{Na}^{+}$from aqueous solution using $\mathrm{AC}$, a comparison was done between $\mathrm{AC}$ and other adsorbents such as eggshell derived $\mathrm{CaO}$ and $\mathrm{CaO} / \mathrm{Fe}_{3} \mathrm{O}_{4}$ composite and the results are shown in Figure 12. The experiments were done under optimal conditions such as $\mathrm{pH}$ of 11 , contact time of $45 \mathrm{~min}$, adsorbent dosage of $5 \mathrm{~g} / \mathrm{L}$, temperature of $25^{\circ} \mathrm{C}$ and sodium ion concentration of $900 \mathrm{mg} / \mathrm{L}$. As shown, the removal efficiency of $\mathrm{Na}^{+}$using $\mathrm{AC}(95.91 \%)$ is higher than $\mathrm{CaO}(83.45 \%)$ and $\mathrm{CaO} / \mathrm{Fe}_{3} \mathrm{O}_{4}(89.2 \%)$, indicating the high performance of $\mathrm{AC}$ compared to the other two adsorbents.

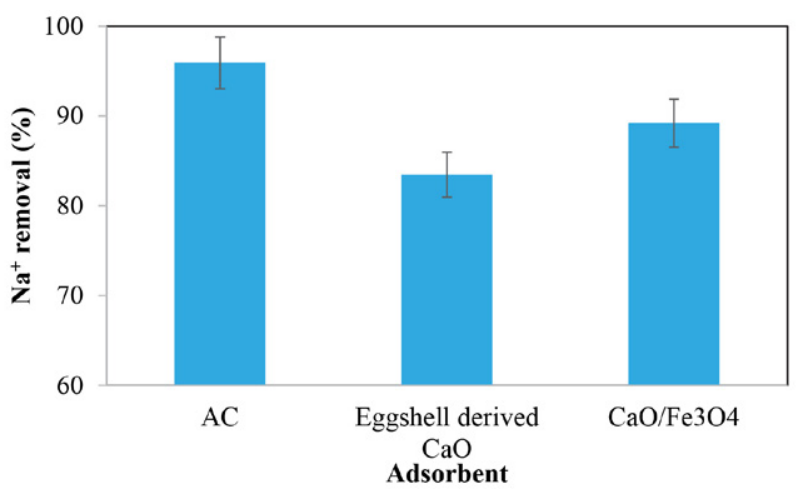

Figure 12. The removal efficiency of the adsorbents at optimal conditions $(\mathrm{pH}=11$, time $=45 \mathrm{~min}$, adsorbent dosage $=5 \mathrm{~g} / \mathrm{L}$, temperature $=25^{\circ} \mathrm{C}$ and initial sodium concentration $=900 \mathrm{mg} / \mathrm{L}$ )

\section{Conclusion}

The obtained results indicated that the AC made from Moringa oleifera plant is an effective adsorbent for the removal of sodium ion from aqueous solutions. Based on the present study, removal of sodium ion increases with increasing contact time and $\mathrm{pH}$ at room temperature however, it has an opposite relationship with the enhancement of sodium ion concentration. Furthermore, the studies indicated that the maximum sodium ion removal efficiency of $95.91 \%$ was achieved at contact time of $45 \mathrm{~min}$, adsorbent dosage of $5 \mathrm{~g} / \mathrm{L}$, and $\mathrm{pH}$ of 11 . Also, the equilibrium and kinetic studies indicated that the equilibrium data were better explained by the Langmuir isotherm than the Freundlich isotherm and the best kinetic correlation for sodium adsorption by the adsorbent in laboratory conditions follows the QSO kinetic model. Furthermore, the thermodynamic behavior of the $\mathrm{Na}^{+}$ion process indicated that the sodium ion sorption by the AC is spontaneous, exothermic, and possible. Moreover, the maximum uptake capacity of $\mathrm{Na}^{+}$ion was obtained $249.67 \mathrm{mg} / \mathrm{g}$, which was a significant amount. Generally, Moringa oleifera can be used as an effective adsorbent for the removal of $\mathrm{Na}^{+}$ion from water and wastewater due to its benefits such as cheapness, nativity, and availability.

\section{Disclosure statement}

No potential conflict of interest was reported by the authors. 


\section{Reference}

1. L. He, M. X. Li, F. Chen, S.S. Yang, J. Ding, L. Ding, N.Q. Ren, J. Hazard. Mater. 2021, 417, 126113.

DOI:10.1016/j.jhazmat.2021.126113

2. S. Yang, Z. Li, K. Yan, X. Zhang, Z. Xu, W. Liu, Z. Liu, H. Liu, J. Environ. Sci. 2021, 103, 59-68. DOI:10.1016/j.jes.2020.10.013

3. M. Fathy, M. A. Mousa, T. A. Moghny, A. E. Awadallah, Appl. Water Sci. 2017, 7, 4427-4435.

DOI:10.1007/s13201-017-0588-3

4. A. M. Siemens, J. J. Dynes, W. Chang, Environ. Technol. 2020. DOI: $0.1080 / 09593330.2020 .1721567$

5. L. He, Y. Chen, J. Li, Resour. Conserv. Recycl., 2018, 133, 206228. DOI:10.1016/j.resconrec.2018.02.015

6. K. C. Khulbe, T. Matsuura, Appl. Water Sci. 2018, 8, 19. DOI:10.1007/s13201-018-0661-6

7. Q. Guan, G. Zeng, J. Song, C. Liu, Z. Wang, S. Wu, J. Environ. Manage. 2021, 293, 112961.

DOI:10.1016/j.jenvman.2021.112961

8. J. S. George, A. Ramos, H. J. Shipley, J. Environ. Chem. Eng. 2015, 3, 969-976. DOI:10.1016/j.jece.2015.03.011

9. S. Ren, B. Ye, S. Li, L. Pang, Y. Pan, H. Tang, Nano Res. 2021. DOI:10.1007/s12274-021-3694-3

10. A. Garg, M. Mainrai, V. K. Bulasara, S. Barman, Chem. Eng. Commun. 2015, 202, 123-130.

DOI:10.1080/00986445.2013.836636

11. T. Jesionowski, J. Zdarta, B. Krajewska, Adsorption, 2014, 20, 801-821. DOI:10.1007/s10450-014-9623-y

12. X. Cheng, L. He, H. Lu, Y. Chen, L. Ren, J. Hydrol., 2016, 540, 412-422. DOI:10.1016/j.jhydrol.2016.06.041

13. S. Abbasi, R. Foroutan, H. Esmaeili, F. Esmaeilzadeh, Desalin. Water Treat. 2019, 141, 269. DOI:10.5004/dwt.2019.23569

14. R. Salahshour, M. Shanbedi, H. Esmaeili, Acta Chim. Slov. 2021, 68, 363-373. DOI:10.17344/acsi.2020.6311

15. A. R. Lucaci, D. Bulgariu, I. Ahmad, G. Lisă, A. M. Mocanu, L. Bulgariu, Water, 2019, 11, 1565 . DOI:10.3390/w11081565

16. A. Attarad, Z. Hira, Z. Muhammad, H. Ihsanul, P. Abdul Rehman, S. Joham, H. Altaf, Nanotechnol. Sci. Appl. 2016, 9, 49-67. DOI:10.2147/NSA.S99986

17. S. M. Mousavi, S. A. Hashemi, H. Esmaeili, A. M. Amani, F. Mojoudi, Acta Chim. Slov. 2018, 65, 750-756.

DOI:10.17344/acsi.2018.4536

18. A. A. Alqadami, M. Naushad, Z. A. Alothman, M. Alsuhybani, M. Algamdi, J. Hazard. Mater. 2020, 389, 121896. DOI:10.1016/j.jhazmat.2019.121896

19. R. Foroutan, R. Mohammadi, S. Farjadfard, H. Esmaeili, B. Ramavandi, G.A. Sorial, Adv. Powder Technol. 2019, 30, 2188-2199. DOI:10.1016/j.apt.2019.06.034

20. S. M. Jamil, M. W., Ali, A. Ripin, A. Ahmad, J. Appl. Sci. 2015, 15, 516-523. DOI:10.3923/jas.2015.516.523

21. R. Rostamian, M. Heidarpour, S. F. Mousavi, M. Afyuni, J. Agr. Sci. Tech. 2018, 17, 1057-1069.

22. R. Caletka, C. Konečný, M. Šimková, J. Radioanal. Chem. 1972, 10, 5-15. DOI:10.1007/BF02518760

23. S. Yang, X. Wan, K. Wei, W. Ma, Z. Wang, Miner. Eng. 2021, 169, 106966. DOI:10.1016/j.mineng.2021.106966
24. Z. Wang, Q. Lei, Z. Wang, H. Yuan, L. Cao, N. Qin, Z. Lu, J. Xiao, J. Liu, Chem. Eng. J. 2020, 395, 125180.

DOI:10.1016/j.cej.2020.125180

25. K. Zhang, L. Qiu, J. Tao, X. Zhong, Z. Lin, R. Wang, Z. Liu, Hydrometallurgy 2021, 205, 105722.

DOI:10.1016/j.hydromet.2021.105722

26. Z. Fan, P. P. Ji, J. Zhang, D. Segets, D. R. Chen, S. C. Chen, J. Membr. Sci. 2021, 635, 119503.

DOI:10.1016/j.memsci.2021.119503

27. Q. Pan, Y. Zheng, Z. Tong, L. Shi, Y. Tang, Angew. Chem. Int. Ed. 2021, 60, 11835-11840. DOI:10.1002/anie.202103052

28. R. Chen, Y. Cheng, P. Wang, Y. Wang, Q. Wang, Z. Yang, C. Tang, S. Xiang, S. Luo, S. Huang, C. Su, Chem. Eng. J. 2021, 421, 129682. DOI:10.1016/j.cej.2021.129682

29. X. Li, T. Shi, B. Li, X. Chen, C. Zhang, Z. Guo, Q. Zhang, Mater. Des. 2019, 183, 108152. DOI:10.1016/j.matdes.2019.108152

30. R. Wang, Y. Yuan, J. Zhang, X. Zhong, J. Liu, Y. Xie, S. Zhong, Z. Xu, J. Power Sources 2021, 501, 230006. DOI:10.1016/j.jpowsour.2021.230006

31. S. Yang, X. Wan, K. Wei, W. Ma, Z. Wang, Waste Manage. 2021, 120, 820-827. DOI:10.1016/j.wasman.2020.11.005

32. R. Chen, Y. Cheng, P. Wang, Q. Wang, S. Wan, S. Huang, R. Su, Y. Song, Y. Wang, Sci. Total Environ. 2021, 756, 143871. DOI:10.1016/j.scitotenv.2020.143871

33. H. Yin, C. Han, Q. Liu, F. Wu, F. Zhang, Y. Tang, Small 2021, 17, 2006627. DOI:10.1002/smll.202006627

34. R. Foroutan, R. Mohammadi, H. Esmaeili, F.M. Bektashi, S. Tamjidi, Waste Manage. 2020, 105, 373-383.

DOI:10.1016/j.wasman.2020.02.032

35. H. Li, B. Xu, G. Lu, C. Du, N. Huang, Energy Convers. Manag. 2021, 236, 114063. DOI:10.1016/j.enconman.2021.114063

36. G. Abbas, I. Javed, M. Iqbal, R. Haider, F. Hussain, N. Qureshi, Desalin. Water Treat. 2017, 95, 274-285.

DOI:10.5004/dwt.2017.21465

37. I. Khoshkerdar, H. Esmaeili, Acta Chim. Slov. 2019, 66, $208-$ 216. DOI:10.17344/acsi.2018.4795

38. L. P. Lingamdinne, J. S. Choi, J. K. Yang, Y. Y. Chang, J. R. Koduru, J. Singh, Acta Chim. Slov. 2018, 65, 599-610. DOI:10.17344/acsi.2018.4254

39. D. Humelnicu, M. Ignat, M. Suchea, Acta Chim. Slov. 2015, 62, 947-957. 2016, 107, 012067. DOI:10.17344/acsi.2014.1825

40. W. Y. Huang, G. Q. Wang, W. H. Li, T. T. Li, G. J. Ji, S. C. Ren, M. Jiang, L. Yan, H. T. Tang, Y. M. Pan, Y. J. Ding, Chem 2020 , 6, 2300-2313. DOI:10.1016/j.chempr.2020.06.020

41. A. Awwad, M. Amer, M. Al-aqarbeh, Chem. Int. 2020.

42. W. Y. Huang, D. Li, Z. Q. Liu, Q. Tao, Y. Zhu, J. Yang, Y. M. Zhang, Chem. Eng. J. 2014, 236, 191-201.

DOI:10.1016/j.cej.2013.09.077

43. F. Takmil, H. Esmaeili, S.M. Mousavi, S.A. Hashemi, $A d v$. Powder Technol. 2020, 31, 3236-3245.

DOI:10.1016/j.apt.2020.06.015

44. J. Fu, Z. Chen, M. Wang, S. Liu, J. Zhang, J. Zhang, Q. Xu, Chem. Eng. J. 2015, 259, 53-61. DOI:10.1016/j.cej.2014.07.101

45. Z. Li, M. Peng, X. Zhou, K. Shin, S. Tunmee, X. Zhang, C. Xie, H. Saitoh, Y. Zheng, Z. Zhou, Y. Tang, Adv. Mater. 2021, 2100793. DOI:10.1002/adma.202100793 


\section{Povzetek}

Namen študije je bil določiti optimalni adsorbent izmed aktivnega oglja na osnovi Moringa oleifera (AC), CaO nanodelcev pridobljenih in jajčnih lupin in $\mathrm{CaO} / \mathrm{Fe}_{3} \mathrm{O}_{4}$ za odstranjevanje natrijevih $\left(\mathrm{Na}^{+}\right)$ionov iz vodnih raztopin. $\mathrm{V}$ prvem koraku smo določili njihovo adsorpcijsko učinkovitost, pri čemer se je AC adsorbent izkazal kot najboljši. Z metodologijo odzivnih ploskev (ang. response surface methodology - RSM) smo ovrednotili vpliv različnih parametrov na učinkovitost adsorpcije $\left(\mathrm{Na}^{+}\right)$ionov AC adsorbenta. Najvišja učinkovitost odstranjevanja pod optimalnimi pogoji je znašala 95.91 $\%$, pri pH vrednosti 11 , kontaktnem času $45 \mathrm{~min}$, temperaturi $25^{\circ} \mathrm{C}$, koncentraciji natrijevih ionov $900 \mathrm{mg} / \mathrm{L}$ in količini adsorbenta $5 \mathrm{~g} / \mathrm{L}$. Optimalni pogoji določeni z uporabo genetskih algoritmov pa so bili pri kontaktnem času $94.97 \mathrm{~min}$, količini adsorbenta $3.52 \mathrm{~g} / \mathrm{L}$, koncentraciji natrijevih ionov $939.92 \mathrm{mg} / \mathrm{L}$ in pH vrednosti 10.92. Maksimalna adsorpcijska kapaciteta določena z Langmuirjevim modelom je bila ocenjena na 249.67 mg/g, kar je znatna količina. Poleg tega smo pokazali, da lahko eksperimentalne podatke ravnotežja in kinetike adsorpcije natrijevih ionov dobro opišemo $\mathrm{z}$ Langmuirjevo izotermo in kinetiko adsorpcije psevdo-drugega-reda. Termodinamična analiza je pokazala, da je adsorpcija endotermen proces. Zaključimo lahko, da je predstavlja aktivno oglje, z visoko učinkovitostjo odstranjevanja in visoko adsorpcijsko kapaciteto, obetajoč adsorbent za odstranjevanje natrija iz onesnaženih voda na industrijskem nivoju. 